\title{
Legal Sanctions on Corporation That Do Corruption
}

\author{
Khairul Imam \\ \{khairulimam042@gmail.com\} \\ Faculty of Law University of Lampung, Indonesia
}

\begin{abstract}
KUHP often lags behind the development of crimes that occur in the community so it must be patched to keep up with these developments. Corporate problems as the subject of criminal law, where corporations can carry out criminal acts and can be accounted for. Corruption problems are a problem that is hated by all the international community including the people of Indonesia so that since the reforms were rolled out in Indonesia this has been highlighted by various parties or it can be said that the problem of corruption is given priority to eradication.
\end{abstract}

Keywords: Corruption; Legal Sanction on Corporation; Legal Sanction of Corruption

\section{Introduction}

\subsection{Background}

Government policies in an effort to eradicate corruption continue to increase. This is evidenced by the establishment of commission IV, as stipulated in Presidential Decree No. 12 of 1970, with the following tasks:

1. Conducting research and assessment of policies and results achieved in the context of eradicating corruption;

2. Give consideration to the government regarding policies that are still needed in order to eradicate corruption.

On March 12, 1971, was passed into Law No. 3 of 1971 concerning the eradication of Corruption Crimes. Efforts in the handling of criminal acts (criminal policies) in general, especially criminal acts of corruption, can be pursued by using the means of reasoning and non-reasoning in an integrated manner because the means of reason have limited ability to repeat crimes for certain reasons.

Reasoning efforts that have been made are the issuance of various legislative products to eradicate corruption, while the non-reasoning efforts that have been made are the screening of corruptors on television media. Developments in Indonesia in some of the biggest criminal law regulations outside the Criminal Code regulate corporations as criminal offenders and can be punished, for example, Law No. 20 of 2001 concerning Eradication of Corruption Crimes discussed in this paper, the acceptance of corporations as perpetrators of criminal acts and can be convicted, then the interesting thing to study is the problem of corporate and criminal liability that is united in the corporation.

\subsection{Formulation of Problems/Questions}

Based on the things mentioned above associated with the background of the problem, the problems raised in this paper are as follows: 
1. Can corporations be criminally responsible?

2. What forms of criminal liability and sanctions on corporations in criminal acts of corruption?

\subsection{Theory and Related Works}

Justice from Plato (classical age)

1. The government is held by wise people to be fair

2. Law as a means of justice.

3. Fair Law Reality:

a. The best law to deal with injustice.

b. The rule of law must be compiled in one book to avoid chaos.

c. The law must be preceded by a preamble of contents about motives and goals.

\subsection{Search Objectives}

Based on the background of the problems and problems raised above, the objectives of this study are:

1. To find out corporate responsibility in criminal law.

2. To find out the form of corporate criminal liability for corruption.

\section{Methods}

\subsection{Time and Context of Research}

\section{Approach to the Problem}

The approach taken in this study is a normative juridical approach and an empirical juridical approach.

\section{Data Sources and Types}

The data used in this study is data obtained directly from the field (empirical data) and from library materials. Primary data is the result of field research that will be conducted from sources of observation and open and in-depth interviews with officials who are directly involved or know the problem of corporate criminal liability in corruption. Secondary Data is the data used to solve the problem in this study is secondary data, namely data obtained from the results of library research by studying and citing books or literature and applicable legislation and supporting this research. Secondary data consists of 3 legal materials, namely:

Secondary data is data obtained through library research activities by reading, analyzing, recording, analyzing and citing books, laws and several provisions and other literature relating to legal issues that occur include:

1. Primary Law Materials which include:

Primary legal material is in the form of legislation along with the implementing regulations, which consist of:

a. 1945 Constitution The 4th Amendment Result

b. Law of the Republic of Indonesia Number 31 of 1999 concerning Eradication of Corruption Crimes as amended by the Law of the Republic of Indonesia Number 20 of 2001 concerning Amendment to Law Number 31 of 1999 concerning Eradication of Corruption Crimes. 
c. Law Number 8 of 1981 concerning the Criminal Procedure Code;

d. Law Number 2 of 2002 concerning Republic of Indonesia Police;

e. Law Number 16 of 2004 concerning the Republic of Indonesia Prosecutor's Office;

f. Law Number 48 of 2009 concerning Republic of Indonesia Judicial Power;

g. Government Regulation Number 58 of 2010 as amended by Government Regulation Number 92 of 2015 concerning the implementation of the Criminal Procedure Code

2. Secondary Legal Materials

Secondary legal materials that include, documentation or notes, literature relating to this research and observations (observations) in the data field obtained from library studies and interviews with the Lampung Regional Police. Field data were obtained from the Lampung Regional Police. The Lampung High Prosecutor's Office and the Tanjung Karang Corruption Court.

3. Tertiary Legal Materials

Tertiary legal materials are materials relating to primary and secondary legal materials, such as dictionaries, encyclopedias and so on.

4. Primary data

Namely, data sourced and obtained directly from the object of field research and carried out by collecting data, researching and selecting primary data obtained directly from the field, especially from legal practitioners and other related parties.

5. Informant

The informant is someone who can provide clues about the symptoms and conditions relating to an event.26 At this stage using a list of statements that are open where it is done to the parties relating to the problems in this study include:
a. Police in Lampung Region
: 1 person
b. Attorney at the Lampung High Prosecutor's Office
: 1 person
c. The judge at the Tanjung Karang Corruption Court
: 1 person
d. Academics at the University of Lampung
: 1 person
Total
4 persons

\subsection{Tools/ Data Collection Methods}

1. Collection Methods

In collecting data for this thesis research the researcher used 2 types of data collection procedures, namely:

a. Library research

Data collection through this literature study was conducted to study the literature on existing legal materials by reading, quoting, analyzing whether the data is sufficiently complete to be prepared in the process of data verification carried out carefully and adjusted to the subject matter. Field Research.

b. Field research

This research focuses on primary data, so data collection is done openly in-depth inter achieving (open and in-depth interviews) by preparing the main points of the problem can then develop at the time the research took place. At this stage, 
various interviews were conducted with several key informants who were found, namely from the Lampung Regional Police. Because these respondents had vitally related authority, especially in terms of problems in the condition of corruption law enforcement related to corporate criminal liability as perpetrators of corruption. So that later obtained detailed information and resolution of the problem.

2. Data Processing

After secondary data and primary data are obtained, data processing is carried out in the following steps:

a. Data Selection of data that is checked for completeness, clarity, and relevance to the research.

b. Data Classification Data classification is sorting or classifying the data obtained either by literature study or interview results.

c. Data Systematics Data systematics, namely placing data in accordance with predetermined subjects in a practical and systematic manner.

\begin{abstract}
Analysis Methods
After collecting and processing the data, it is then analyzed qualitatively by the normative juridical approach and empirical juridical approach, namely by describing all the results of the research obtained from theory, legislation and field data, according to the nature of the symptoms and events of the law that are linked to the theory criminal law.
\end{abstract}

\title{
3 Results and Discussion
}

\subsection{Definition of Corporate Crime}

In various parties, corporate crime is often confused with various types of crimes, such as occupation crime, professional crime (organized crime), organized crime, a crime against the corporation (crime against corporations) and criminal corporations (corporations as means of committing a crime). Marshall B. Clinard and Peter C Yeager give an understanding of crime as follows: A corporation committed to being punished by the state, regardless of whether it is finished under administrative, civil, or criminal law (corporate crime is every action which is carried out by corporations that can be punished by the State, whether under state administrative law, civil law or criminal law.

Corporate crime is carried out for the benefit of the corporation and not vice versa, a crime against a corporation called employee crimes is a crime committed by employees of a corporation, such as embezzlement of company funds by an official or employee of the company. Whereas being criminal corporations is a corporation that is deliberately formed and controlled to commit a crime. The position of the corporation here is merely a means of committing a crime "mask" to hide the real face of a crime. The usual pattern is that a legal entity seeks to be determined for legitimate purposes and then develops within the limits of an illegal organization indicated for the crime. The important thing to distinguish between crime for corporations is related to the perpetrators and the results of the crimes they have obtained. The perpetrators of crime in corporate crime are the corporation itself. Whereas perpetrators in criminal corporations are criminals outside the corporation, and the corporation is only a means to commit crimes. The proceeds of crime in corporate crime are in the interests of the corporation itself. 


\subsection{Corporate Criminal Liability System}

With regard to criminal liability, the main principle that applies is that there must be an error (Schuld) on the perpetrator according to the notion of error (Schuld) having three special tents, namely:

1. Responsible ability of people who commit actions.

2. Certain inner relationships of people who do their actions can be intentional or negligent.

3. There is no basis for removing the responsibility for the creator for his actions.

To determine the ability of corporate responsibility as the subject of a criminal offense, this is not easy because the corporation as a subject does not have the obligation (spirituality) like natural people (Natuurlijk Persoon). And because the corporation has been recognized as the subject of law, all the effects of the activities it causes that are negative towards the general welfare can be accounted for criminally. At present corporations or business entities in the business world can be extensively liable for crimes or crimes committed by corporate agents acting on behalf of the corporation.

Relating to the form of accountability of a legal entity (corporation), which is about the punishment imposed on a legal entity (corporation) itself. In terms of according to S.R Sianturi, it has been concluded about the provisions regarding the punishment of a legal entity or union, including:

1. That the punishment is in principle not directed at a legal entity or union, but actually to a group of people who work together for a purpose or who have shared wealth for a purpose incorporated in the agency.

2. There are several provisions that must deviate from the application of criminal law (general) against these bodies in the event that the body can be convicted, such as the possibility of imposing a criminal deprivation of liberty (Prison, Confinement) on him, and the possibility of criminal penalties being replaced with imprisonment.

If we want to connect the perpetrators with their actions in order to account for the speech of the perpetrators, it must be examined and proven that:

1. The subject must be in accordance with the formulation of the Act.

2. There is an error in action.

3. The act is illegal.

4. The act is prohibited and threatened by criminal law, and

5. The action is carried out in accordance with the place, time, and other conditions specified in the law.

In the development of Indonesian criminal law, there are three systems of corporate responsibility as the subject of criminal acts, namely (1) Corporate administrators as makers, then the administrators are responsible, (2) Corporations as makers, then responsible managers (3) Corporations as responsible and responsible. The regulation of corporations as the subject of criminal acts in our positive criminal law turns out to be very diverse. The development of corporate regulation as the subject of criminal acts can be clarified based on three systems of accountability, which are explained in detail as follows:

\section{Corporate Managers As Makers, Then Administrators Are Responsible}

This system of accountability is characterized by efforts to ensure that the nature of criminal acts committed by corporations is limited to individuals (natuurlijk Persoon). So that if a criminal act occurs within the corporation's environment, then the criminal act is deemed to be carried out by corporate management. In connection with the development of the concept of corporation as a subject matter, it can be stated that the general provisions of the Indonesian 
criminal law (KUHP) currently in effect still adhere to that a criminal can only be committed by humans while corporations according to the theory of physics from Von Savigny are legal subjects. Provisions that indicate that acts can only be committed by human beings are Article 51 WVS Netherlands or Article 59 of the Criminal Code, which reads, "in cases where violations are determined criminal against the management, members of the governing body or commissioner, then administrators, management body members who apparently do not interfere committing a criminal offense ". By looking at the above provisions, it can be seen that the previous compilers of the Criminal Code were influenced by the principle of nonpotent societies delinquent or no protest delinquent universities, ie legal entities cannot commit a crime.

\section{Corporations As Makers, Then Administrators Are Responsible}

The second system of corporate responsibility is marked by a recognition that arises in the formulation of the Law that a crime can be committed by a union or business entity, but that responsibility is a burden on the management of the corporation. Slowly criminal responsibility shifts from members of the management to those who order, or with a prohibition to do it if it actually leads the corporation. In this system of accountability, corporations can become makers of criminal acts, but those responsible are the members of the board.

\section{Corporations as Makers and Responsible}

This third system of accountability is the beginning of the immediate responsibility of the corporation. In this system, the possibility is opened according to the corporation and holds accountable according to criminal law. Things that can be used as the basis of justification or the reason that the corporation as the maker of and also responsible are as follows: First, because in various economic crimes, profits obtained by the corporation or losses suffered by the community can be so large that it will not be balanced if the criminal is only dropped only to the board. Second, by only convicting the management, there is no or no guarantee that the corporation will not repeat the crime again.

By convicting corporations of the type and weight in accordance with the nature of the corporation, it is expected that the corporation can comply with the relevant regulations. In this third system of accountability, there has been a shift in view, that corporations can be held accountable for this third, there has been a shift in view, that corporations can be accounted as makers, besides natural people (naturlijk persoon). So the refusal of corporate punishment based on the doctrine of the non-potent delinquent university has undergone a change by accepting the concept of a functional actor (functioneel daderschap).

\subsection{Form of Corporate Responsibility in Corruption Crimes}

The word of responsibility comes from a word of responsibility, that is, an offense of responsibility and crime is an audible phrase and is used in daily conversation both moral, religious, and legal. The three elements are related to one another and are rooted in the same state that the breach of a system of rules may be broad and diverse, covering civil law and criminal law and moral rules. Responsible for a crime means that the lawful person may be subject to criminal penalties for the action he has committed. A criminal offense can be legally sanctioned if for that action there is already a rule in a relationship system and the system is applicable to that action. In other words, the action is not allowed by the system.

Here is the basic concept. The law aims to achieve justice and justice is commonly interpreted in common. In the use of criminal sanctions as one of the means of social sanction 
in all limitations. Muladi said that the conditions for optimally using criminal sanctions must include:

1. The prohibited acts, according to most members of the community, are considered strikingly harmful to the community, considered important by the community.

2. The application of criminal sanctions against acts that are prohibited is consistent with the objectives of punishment.

3. The eradication of these acts, will not experience or hinder the desired behavior of the community.

4. Such behavior can be understood in ways that are not biased and not discriminatory.

5. Arrangement through the process of criminal law, will not give a heavy impression, both qualitatively and quantitatively.

6. There are no choices based on the criminal sanction, to deal with this behavior.

7. With the existence of Law No. 31 of 1999 Jo. Law 20 of 2001, Law 3 of 1971 concerning the eradication of criminal acts of corruption is not in accordance with the development of legal needs in society, which is expected to be more effective in preventing and eradicating criminal acts of corruption. In Law 31 of 1999, there are several formulations of corruption offenses, formally formulated which are adopted in this law, even though the results of corruption have been returned to the State, perpetrators of corruption are still sent to court and remain convicted.

\subsection{Criminal Imposition of Corporations in Corruption Crimes}

In article 20 paragraph (1) Law No. 20 of 2001 stipulates that: "In the case of a criminal act carried out by or on behalf of a corporation, then the demands and imposition of criminal acts can be carried out against the corporation and/or its management".

So what can be accounted for is:

1. Corporate;

2. The management;

3. Corporations and their influence.

Suprapto also stated that the penalties that can be imposed on companies are:

a. The closing of all or part of the company of the convicted person for a certain period of time;

b. Revocation of all or part of certain facilities that have been or can be obtained from the government by the company for a certain period of time.

c. of companies under forgiveness for a certain period of time.

\section{Conclusion and Recommendation}

\subsection{Conclusion}

1. The corporation is a business entity whose existence and legal status are equated with humans (people), regardless of the shape of the organization. Corporations can have wealth and debt, make claims, and be sued before the court. Whereas corporate crime is any action taken by a corporation that can be punished by the State, both in the punishment of state administration, civil law and criminal law. In this case, the penalty that can be imposed on the company (corporation) is the closure of all or part of the corporation (corporations), the revocation of certain facilities obtained from the government, placement of companies under forgiveness for a certain period of time, 
criminal penalties, civil sanctions or compensation. So with this, it can be concluded that the system of corporate accountability as the subject of criminal acts, namely the corporate management as the maker, the management is responsible, the corporation as the maker and responsible. The corporate responsibility in the Criminal Code is in accordance with article 59 of the responsible officials, article 169 paragraph (2), article 378 benefits themselves / others.

2. The legal subject in the Corruption Eradication Act is: every person or corporation (article 2 paragraph (1) and article 3). Legal subjects who can be snared as perpetrators of criminal acts of corruption are not only individual individuals (their capacity as private persons or civil servants), but also a corporation, corporate criminal responsibility for criminal acts of corruption.

\subsection{Recommendation}

1. In terms of criminal liability against corporations, it should be viewed from various sides, this is because if the corporation is given criminal liability that is very ineffective, it can have an adverse effect on those who do not participate in committing the corporate crime. Such as employees or workers who can be negatively affected by the implementation of corporate criminal sanctions that are less effective, so that in this case law enforcers must be truly wise in deciding the imposition of criminal sanctions on corporations in accordance with the laws and regulations.

2. In the case of corporate responsibility for criminal acts of corruption, law enforcers should see appropriate and effective sanctions against corporations that commit such crimes. So that it not only creates a deterrent effect for the actors in the corporation itself, but also creates justice for all Indonesian citizens so that the ideals of the State of Indonesia, namely the creation of justice and free corruption are truly realized in our country.

\section{References}

[1] Dirdjosisworo, Soedjono. (1990). Kejahatan Mafia. Bandung: Armico.

[2] Dwidja Priyatno, Kebijakan Legislasi tentang Sistem Pertanggungjawaban Pidana Korporasi Di Indonesia, CV Utomo, Bandung, 2004.

[3] Hatrik, Hamzah, Azas Pertanggungjawaban Korporasi dalam Hukum Pidana Indonesia (Strict Liability dan Vicarious Liability), Raja Grafindo, Jakarta, 1996.

[4] Heriyandi, Teori Hukum, bahan kuliah teori hukum, 2018.

[5] Muladi, Fungsionalisasi Hukum Pidana di dalam Kejahatan Korporasi, Alumni, Bandung, 1990.

[6] Muladi, Penerapan Pertanggungjawaban Korporasi Dalam Hukum Pidana, bahan kuliah kejahatan korporasi, 1996.

[7] Sianturi S.R, Asas-Asas Hukum Pidana Di Indonesia dan Penerapannya, Ahacm-petehaem, Jakarta, 2000.

[8] Undang-undang Nomor 20 tahun 2001 tentang Pemberantasan Tindak Pidana Korporasi. 2001. Jakarta

[9] Undang-undang Nomor 30 tahun 2002 tentang Komisi Pemberantasan Korupsi. 2002. Jakarta.

[10] Undang-undang Nomor 15 tahun 2002 tentang Tindak Pidana Pencucian Uang. 2002. Jakarta.

[11] Undang-undang Nomor 5 tahun 1997 tentang psikotropika. 1997. Jakarta.

[12] Weda, Made Darma, Beberapa Catatan Tentang Kejahatan Korporasi, ghalia, Jakarta, 1993. 